\title{
Problemy szkolnictwa i oświaty na łamach prasy olsztyńskiej (1945-1947)
}

Kształtujący się w Polsce, po II wojnie światowej, system prasowy nie mógł być - w nowych warunkach ustrojowych - kontynuacją tradycji czasopiśmienniczej poprzednich okresów. Zmiany miały być radykalne ${ }^{1}$ i zakładały:

- likwidację prywatnej formy własności wydawnictw prasowych, wprowadzenie systemu koncesyjnego, cenzury, reglamentacji papieru,

- stworzenie warunków do upowszechnienia czytelnictwa pracy co miało umożliwić realizację zapowiadanego przez nowe władze programu demokratyzacji kultury,

- pełną "reprezentację prasową" tych sił politycznych, które poparły nową władzę przy zachowaniu uprzywilejowanej pozycji partii komunistycznej (PPR),

- nawiązywaniu w miarę potrzeby do tytułów i wzorów czasopiśmienniczych z okresu międzywojennego, które uznano za „postępowe i demokratyczne” po to, aby podkreślić ewolucyjny a nie rewolucyjny charakter zmian ustrojowych - różnicowaniu się prasy pod względem tematycznym, pełnionych funkcji i adresata oraz unikania natrętnej indoktrynacji,

- zaangażowania prasy na rzecz walki zbrojnej z Niemcami, odbudowy zniszczeń wojennych i afirmowania poczynań władzy².

W latach 1945-1946 rozwój prasy w Polsce był stosunkowo dynamiczny, ale zarazem żywiołowy i charakteryzował się kształtowaniem systemów prasowych partii politycznych. Wyrazem tego jest fakt, że pod koniec 1946 r. wychodziło już 618 tytułów prasowych, w tym 53 dzienniki, które wydawane były we wszystkich województwach oraz 565 periodyków. Jednak już w 1947 r. zlikwidowano 60 tytułów prasowych, a dla kilkudziesięciu innych ograniczono przydział papieru.

* Dr hab., prof. WSInf, Katedra Pedagogiki i Studiów Edukacyjnych, Wydział Pedagogiki i Promocji Zdrowia, Wyższa Szkoła Informatyki i Umiejętności, 93-008 Łódź, ul. Rzgowska 17a.

** Dr, Katedra Dydaktyki i Historii Wychowania, Wydział Nauk Społecznych, Uniwersytet Warmińsko-Mazurski, 10-725 Olsztyn, ul. Prawocheńskiego 13.

1 Kluczową rolę w tych zmianach odegrał Jerzy Borejsza, który otrzymał nominację na redaktora naczelnego „Rzeczpospolitej” - organu prasowego PKWN.

2 D. G r z e l e w s k a i in., Prasa, radio i telewizja w Polsce. Zarys dziejów, Warszawa 2001, s. 144. 
Postanowiono też nie wydawać zezwoleń na edycję nowych tytułów prasowych do 1 września 1947 r. Decyzja ta była wynikiem wcielenia w życie polityki informacyjnej, propagandowej i wydawniczej PPR, która zakładała ujednolicenie treści większości gazet i czasopism³ ${ }^{3}$.

Powyższe fakty i uwarunkowania ogólnopolskie znalazły swoje odzwierciedlenie w tworzeniu prasy w Olsztyńskiem, gdzie w latach 1945-1947 powstały i wydawane były dwa tytuły prasowe: „Głos Ziemi” (fot. 1) i „Wiadomości Mazurskie" (fot. 2).

Pierwszy - w maju 1945 r. - ukazał się „Głos Ziemi” jako organ prasowy Zarządu Okręgowego Stronnictwa Ludowego Ziemi Mazurskiej. W słowie od redakcji tak określono założenia programowe gazety oraz jej adresatów:

Wydajemy go jako pierwszą gazetę polską w wyzwolonej z długowiekowej niewoli Ziemi Mazurskiej. Przeznaczamy ją dla Ludu. Dla Ludu pracującego wsi i miast naszych. Niechaj polskie słowo dotrze do każdej chałupy, do każdego poddasza. „Ojców mowo słyń na nowo”. „Głos Ziemi” jest dalszym ogniwem w prasie miejscowej Ziemi Mazurskiej. [...] „Głos Ziemi” jak i jego poprzednicy, niechaj buduje polskość na tych odwiecznie polskich ziemiach. Niechaj jednoczy zahartowanych w długich bojach o ojców mowę Warmiaków i Mazurów z Braćmi z Warszawy, Krakowa, Poznania, Torunia, Lublina i każdego zakątka ziemi, gdzie brzmi polskie słowo. „Głos Ziemi” niech będzie kamieniem do fundamentu, na którym stanie silny gmach nie-

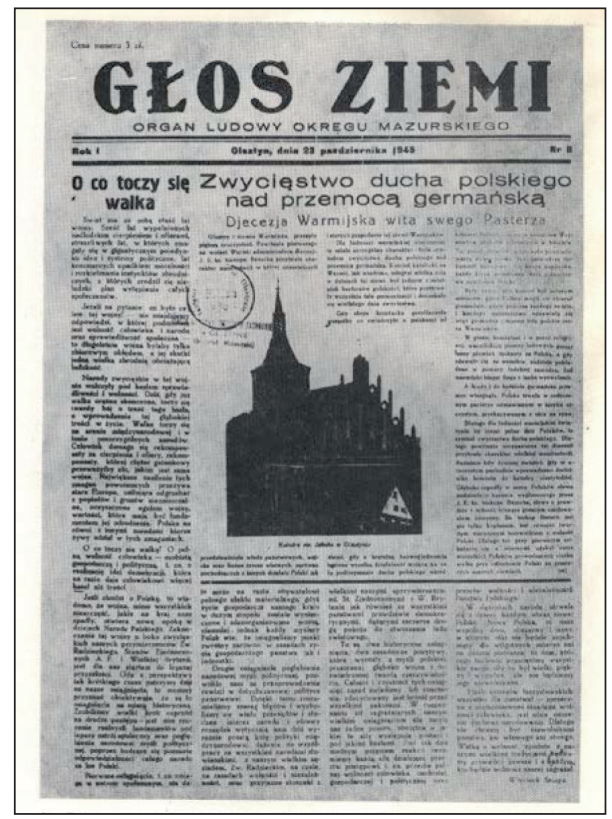

Fot. 1. Pierwszy drukowany numer „Głosu Ziemi”, 23 października 1945 r. zależnej, silnej, równej i demokratycznej Nowej Polski ${ }^{4}$.

\section{Pierwsze numery „Głosu Ziemi”} były wydane na powielaczu, miały przede wszystkim charakter informacyjny i zawierały takie elementy, jak: artykuły, cykl „Na Mazurach”, wiersz, „Wiadomości agencyjne ze świata”, informacje „Z życia Olsztyna”.

Dopiero 23 października 1945 r. ukazał się drukowany numer gazety, jednak już z końcem 1945 r. zaprzestano wydawania pisma. Próbę reaktywowania "Głosu Ziemi" podjęto w 1946 r., lecz wówczas ukazał się tylko jeden numer (17 marca), noszący podtytuł "Tygodnik społeczno-gospodarczy"s. Najczęściej na łamach pisma poruszano problematykę ludności rodzimej, spustoszenia moralnego, będącego wynikiem wojny, dewastacji życia go-

3 Tamże, s. 149-150.

4 „Głos Ziemi” [dalej: GZ] 1945, nr 1, za: B. Łuka s ze w i c z, Prasa informacyjno-polityczna Warmii i Mazur 1945-1975, Warszawa 1982, s. 51.

${ }^{5}$ W 1948 r. ponownie podjęto próbę wznowienia pisma, lecz wydano wówczas jedynie trzy numery - jednodniówki posiadające okolicznościowy charakter. 
spodarczego, ciężkiej sytuacji aprowizacyjnej, różnych przejawów życia społecznego, walki o polskość. Najwięcej miejsca poświęcono zagadnieniom społecznym (około $28 \%$ całej objętości wszystkich numerów pisma), tematyce politycznej (około 15\%), regionalnej tematyce historycznej (około 11\%). Poza wymienionymi tematami, żadna inna problematyka nie zajęła więcej niż $10 \%$ objętości pisma, a zaledwie około $27 \%$ zawartości treściowej wszystkich numerów „Głosu Ziemi” poświęcono problematyce administracji, ideologii, sportu, gospodarki, obronności, kultury, wychowania, szkolnictwa i oświaty ${ }^{6}$. Oznacza to, że interesująca nas problematyka była marginalnie potraktowana na łamach „Głosu Ziemi”.

„Wiadomości Mazurskie” powstały z inicjatywy Wojewódzkiego Urzędu Informacji i Propagandy w Olsztynie. Wydawane były od 1 sierpnia 1945 r. trzy razy w tygodniu, w objętości jednokartkowej, formacie kancelaryjnym (A-4), na papierze pakowym. W okresie do października 1945 r. ukazało się 36 egzemplarzy jednokartkowych, następnie wydawanie pisma zostało przerwane w efekcie zmian w „składzie redakcyjnym”. Od 15 grudnia 1945 r. „Wiadomości” ukazywały się jako popołudniówka, a ich ostatni numer wydano 30 kwietnia 1947 r. Likwidacja czasopisma była skutkiem rozwiązania Ministerstwa Informacji i Propagandy i większości firmowanych przez nie wydawnictw ${ }^{7}$. Likwidowane pismo przejęła Spółdzielnia Wydawniczo-Oświatowa „Czytelnik” w celu kolportowania w Olsztyńskiem mutacji „Życia Warszawy”.

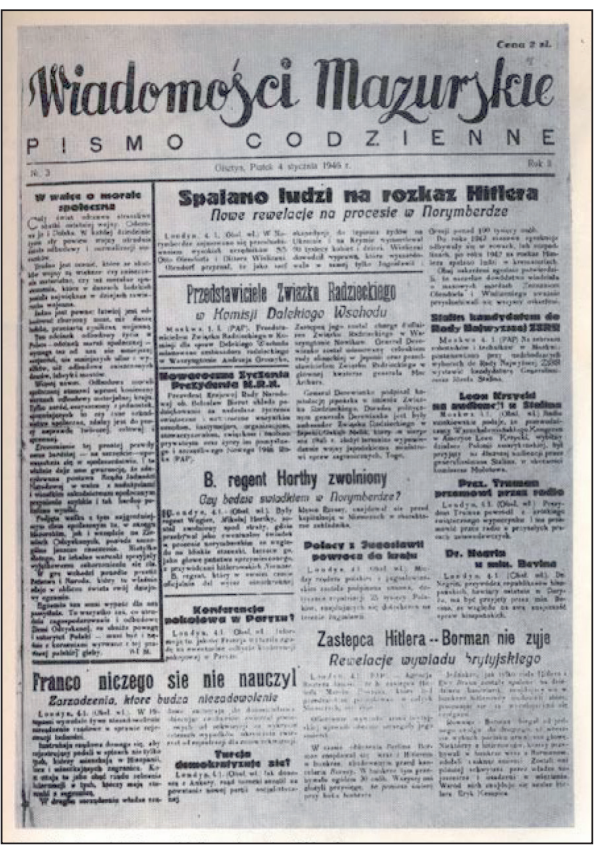

Fot. 2. „Wiadomości Mazurskie”, styczeń $1946 \mathrm{r}$.
„Wiadomości Mazurskie” w zamierzeniach organizatorów miały wypełniać lukę związaną z brakiem prasy codziennej w Olsztyńskiem i „od początku, jako główny cel swego istnienia zakładały informowanie społeczeństwa, integrację środowiska olsztyńskiego oraz służbę tzw. «nowej demokracji». Faktycznie jednak, były narzędziem propagandowym $\mathrm{i}$ «pismo to odegrało istotną rolę w oddziaływaniu na społeczeństwo w duchu programu głoszonego przez Polską Partię Robotniczą»"8. Wśród różnorakiej tematyki poruszanej na łamach czasopisma najwięcej uwagi poświęcono aktualnym problemom regionu. Informowano o warunkach osadnictwa miejskiego i wiejskiego na Warmii i Mazurach, w tym o negatywnych zjawiskach towarzyszących akcji osiedleńczej (np. szabrownictwo i nadużycia gospodarcze), potrzebach

6 B. Łu k a s z e w i c z, Prasa informacyjno-polityczna..., s. 64-66.

7 B. Łu k a s z e w i c z, Prasa Warmii i Mazur w latach 1945-1989, Olsztyn 1991, s. 1.

8 Tamże. 
i problemach integracji społecznej, problemach ludności autochtonicznej, zagadnieniach politycznych (zwłaszcza dotyczących działalności partii politycznych PPS, PPR, SD i PSL krytycznie oceniając działalność tej ostatniej), referendum 1946 r., wyborów do Sejmu Ustawodawczego 1947 r. ${ }^{9}$ Sporo uwagi poświęcano także sprawom oświatowym, zwłaszcza w porównaniu z omawianiem tej problematyki na łamach „Głosu Ziemi”. Jak stwierdza prof. Bohdan Łukaszewicz - badacz prasy na Warmii i Mazurach - głównym celem dziennika „Wiadomości Mazurskie" było oddziaływanie na czytelnika w duchu programu głoszonego przez Polską Partię Robotniczą. Było to „pismo regionalne ze znaczną zawartością materiałów agitacyjno-propagandowych, spełniających funkcję społecznego oddziaływania na odbiorcę"10.

Z dokonanej charakterystyki celów i zawartości treściowej prasy olsztyńskiej wynika, że tematyka szkolnictwa i oświaty, szczególnie pewnych jej aspektów, była w kręgu zainteresowań redakcyjnych. Poniżej przedstawiamy wybrane zagadnienia, które stały się przedmiotem zainteresowania prasy olsztyńskiej w latach 1945-1947.

W pierwszych latach powojennych na Warmii i Mazurach, oprócz problemów politycznych, gospodarczych i ludnościowych, bardzo istotną sprawą było organizowanie szkolnych i pozaszkolnych placówek oświatowych, pozyskanie odpowiedniej liczby nauczycieli, działalność edukacyjna na rzecz zróżnicowanej pod wieloma względami społeczności regionu. O tych zagadnieniach niejednokrotnie pisano na łamach prasy lokalnej, w tym także w „Wiadomościach Mazurskich” i „Głosie Ziemi”.

Pierwsze szkoły i przedszkola powstały na Warmii i Mazurach w kwietniu 1945 r., zaś jak pisano w „Wiadomościach Mazurskich”: „pierwszą zorganizowaną grupą polskiej ludności napływowej byli nauczyciele-repatrianci ze wschodu. [...] Los ich rzucał w najbardziej nieoczekiwane miejsca, gdzie też powstawały szkoły. Nikt wówczas nie pytał o nominacje, kwalifikacje, uprawnienia, co więcej - nikt z nauczycieli nie liczył na żadne wynagrodzenie"11. Nie były to jednak pełne informacje na temat pierwszych organizatorów szkół, pominięto w artykule nauczycieli warmińskich, uczniów Gimnazjum Polskiego w Kwidzynie oraz nauczycieli - Warmiaków z pochodzenia, uprzednio przygotowanych na kursach językowych, a także tych, związanych w okresie międzywojennym z Polskim Związkiem Zachodnim ${ }^{12}$.

Pomimo braku pełnych informacji na temat stanu kadry nauczycielskiej ciekawe są informacje zamieszczane w czasopismach lokalnych, dotyczące uruchamiania szkół przygotowujących kandydatów do zawodu nauczycielskiego. Przykładem może być artykuł traktujący „[...] o uruchomieniu w Morągu Państwowego Liceum Pedagogicznego, dającego fachowe przygotowanie do zawodu nauczycielskiego. [...] Dla młodzieży z ukończoną szkołą powszechną organizuje

\footnotetext{
9 B. Ł u k a s z e w i c z, Prasa informacyjno-polityczna..., s. 75.

10 Tamże, s. 93.

11 Roczny dorobek nauczycielstwa na odzyskanej ziemi warmińsko-mazurskiej, „Wiadomości Mazurskie" [dalej: WM], 24 XI 1946, s. 3.

12 U. Pulińska, Doskonalenie zawodowe nauczycieli szkół ogólnokształcących na Warmii i Mazurach w latach 1945-1989, Olsztyn 2005, s. 24 [maszynopis rozprawy doktorskiej].
} 
się przy liceum skrócone kursy gimnazjalne. [...] Dla młodzieży warmijskiej i mazurskiej organizuje się wstępny kurs ogólnokształcący"13. Liceum to przeniesiono do Ostródy w 1947 r. Kwestia ta pojawiła się także w następnym artykule z cyklu „Z życia Olsztyna”, w którym tak przedstawiono zadania nowo powstałego Liceum Pedagogicznego w Olsztynie:

Państwowe Liceum Pedagogiczne ma za zadanie kształcenie młodzieży i dorosłych do zawodu nauczycielskiego. [...] Ponadto dyrekcja liceum pedagogicznego organizuje szereg kursów pedagogicznych dla osób pragnących poświęcić się zawodowi nauczycielskiemu. [...] Brak nauczycieli nakłada na organizacje młodzieży obowiązek skierowania do liceum i na kursy najbardziej czynnych i uzdolnionych członków ${ }^{14}$.

W późniejszych numerach „Wiadomości Mazurskich” (do końca istnienia czasopisma) nie kontynuowano jednak bardzo ważnego i trudnego do rozwiązania problemu zapotrzebowania na kadrę pedagogiczną. Brak było też informacji o rozpoczęciu od 1 września 1946 r. działalności liceów pedagogicznych w Mrągowie i Szczytnie, a także w 1947 r. - w Bartoszycach ${ }^{15}$.

Problematyka zapotrzebowania na kadrę nauczycielską była natomiast tematem artykułu zamieszczonego na łamach „Głosu Ziemi”. Podkreśla się w nim udział zasłużonych nauczycieli w odbudowie polskości tych ziem, a także zaangażowanie młodego pokolenia: „ponad 30 dziewcząt, Warmiaczek i Mazurek, ukończyło kurs dla wychowawczyń przedszkola i poszło w teren szczepić myśl i krzewić słowo polskie wśród najmłodszych dzieci”16. W tej samej publikacji pisano też o udziale nauczycieli w procesie repolonizacji: „Szczególne zadanie spełniają tu nauczyciele Mazurzy i Warmiacy, przeważnie starzy, zasłużeni bojownicy, którzy w najcięższym nawet okresie nie wątpili w słuszność sprawy polskiej na tych ziemiach"17.

Oddziaływania wychowawcze i oświatowe na młodzież i dorosłych ukierunkowane były m.in. na szybkie opanowanie języka polskiego przez Mazurów i Warmiaków. W procesie repolonizacji ważną rolę spełniały kursy repolonizacyjne. W „Wiadomościach Mazurskich” poświęcono im kilka artykułów. W jednym z nich pisano:

Kursy te stworzone w lipcu z inicjatywy Oddziału Kobiecego Str. Ludowego, z maleńkiej grupki rozwinęły się do poważnych rozmiarów. Pierwszy stopień - liczący około siedemdziesięciu słuchaczy - daje podstawy do opanowania języka tym wszystkim, którzy pod wpływem niemieckiego terroru zapomnieli już mowę ojczystą. Drugi stopień - mniej liczny - przeznaczony jest dla słuchaczy, którzy język ojczysty zachowali w całym bogactwie gwary warmijskiej czy mazurskiej, a którzy obecnie zaznajamiają się z dorobkiem naszej bogatej kultury ${ }^{18}$.

13 Liceum Pedagogiczne w Morągu, WM, 16-18 VIII 1945, s. 3.

14 Z Życia Olsztyna, WM, 25-27 VIII 1945, s. 2.

15 Szkolnictwo w woj. olsztyńskim w przeddzień reformy. Materiały na sesję WRN w Olsztynie, Olsztyn, czerwiec 1966, Archiwum Państwowe w Olsztynie, zesp. KOS, sygn. 444/25, za: U. P u I i ń sk a, Doskonalenie zawodowe..., s. 64.

16 Młodzież warmijska i mazurska przy pracy wychowawczej, GZ, 16 XII 1945, s. 4.

17 Tamże.

18 Nie rzucim ziemi skąd nasz ród. Choinka na kursach repolonizacyjnych, WM, 22 XII 1945, s. 4. 
Organizatorzy kursu z okazji Świąt Bożego Narodzenia zorganizowali spotkanie gwiazdkowe, na którym, w celu pogłębienia więzi z kulturą i tradycją polską „wrażenie wywołane silnymi akcentami hymnu wzmocniły jeszcze pieśni O Warmio moja miła czy Olsztyński my hufiec, odśpiewane przez Warmiaków i Mazurów. [...] nastąpiły deklamacje chłopców i dziewcząt [...] Zabrzmiały dźwięki pradawnych kolęd w radosnym nastroju serdecznej spójni z odzyskaną Ojczyzną"19. Cała uroczystość zakończyła się rozdaniem skromnych upominków i odśpiewaniem hymnu narodowego.

W lutym 1946 r. dwukrotnie poruszono kwestię kursów repolonizacyjnych na łamach „Wiadomości Mazurskich”. Jak wynika z doniesień prasowych, uroczystość otwarcia kursów w Biskupcu „zbiegła się z 200ną rocznicą urodzin Tadeusza Kościuszki. [...] Na pierwszy kurs zgłosiło się przeszło 40 osób w wieku od 17 do 60 lat”20. Podobny kurs, o czym czytamy w „Wiadomościach Mazurskich”, uruchomiono w Szymanowie, w gminie Pawłowo, w powiecie reszelskim. Szczególnie mocno podkreślano obowiązkowość i punktualność uczestników, pomimo że „niektórzy kursanci mają do przebycia 2, 3 i 5 kilometrów w jedną stronę". W omawianej publikacji zwrócono też uwagę na „brak drukowanego słowa polskiego w postaci książek, gazet, broszur, itp."21 Z okazji Święta Oświaty Komitet Wojewódzki organizujący obchody wzywał czytelników do współpracy w zakresie gromadzenia polskich książek w celu repolonizacji ludności mazurskiej i warmińskiej:

W dniu Święta Oświaty należy przede wszystkim pomyśleć o tym, ażeby rodaków naszych i braci, Mazurów i Warmiaków, którzy odcięci byli przez wieki od Macierzy Polskiej zdobyć, pozyskać dla niej. Polską książkę dać do ręki każdemu Mazurowi i Warmiakowi - młodemu i starcowi - niechaj ją pokocha, niech mu się stanie najmilszym skarbem. Kiedy umiłuje książkę polską - pokocha Polskę, Ojczyznę ojców i dziadów 22 .

Nawiązując do tradycji bożonarodzeniowych, jeden z artykułów zamieszczonych na łamach „Wiadomości Mazurskich” poświęcony został gwiazdce zorganizowanej dla dzieci ze szkół powszechnych. Był to jeden z nielicznych artykułów prasowych traktujący o szkolnictwie najniższego szczebla. Podkreślono w nim ogromny entuzjazm uczestniczących w uroczystości dzieci, ich radość wynikającą z uczestnictwa w tradycyjnych obrzędach świątecznych i możliwości otrzymania prezentu gwiazdkowego. Po stronie organizatorów zaakcentowano zaangażowanie władz w pierwsze Święta Bożego Narodzenia oraz w „utrzymanie ładu wśród rozbawionej młodzieży" ze strony nauczycieli.

W ogromnej Sali Z.O.E.M. zebrało się około 2000 dzieci. Wrzało jak w ulu. [...] Do zebranych przemówił prezydent Pałucki - inicjator akcji gwiazdkowych dla dzieci. W krótkich słowach dał wyraz radości z jaką obchodzimy pierwsze święta Bożego Narodzenia w wolnej Polsce i pierwsze od wielu stuleci na Ziemi Warmijskiej. [...] Z prawdziwym przejęciem dzieci odegrały szopkę. [...] Nastąpiła chwila najbardziej radosna i oczekiwana przez dziatwę: rozdanie paczek gwiazdkowych, pochodzą-

19 Tamże.

${ }^{20}$ Kursy repolonizacyjne i uzupełniające w Biskupcu, WM, 20 II 1945, s. 3.

21 Kursy repolonizacyjne w powiecie reszelskim, WM, 21 II 1945, s. 3.

22 Święto Oświaty, WM, 30 IV 1946, s. 2. 
cych z daru Zarządu Miejskiego, który przeznaczył na ten cel specjalne fundusze. Dzieci otrzymały po $1 \mathrm{~kg}$ cukru, $1 \mathrm{~kg}$ bułki pszennej, konserwy i cukierki. Dzieci warmijskie najbiedniejsze dostały ponadto przydział materiałów włókienniczych ${ }^{23}$.

Jedną z pierwszych powojennych szkół uruchomioną na terenie Olsztyna była Szkoła Muzyczna. Informacje prasowe dotyczące tego wydarzenia pojawiły się w czasopiśmie lokalnym dwukrotnie. W sierpniu i wrześniu 1945 r. odnaleźć można w „Wiadomościach Mazurskich” notatkę zapowiadającą uruchomienie szkoły i organizację pierwszych koncertów. Nabór do szkoły rozpoczął się w dniach 3-5 września, zaś w niedzielę 9 września zaplanowano jej uroczyste otwarcie. Szkoła przeznaczona była dla dzieci od lat 7 i starszych.

Innym tematem prasowym było szkolnictwo zawodowe (w tym rolnicze) na poziomie gimnazjalnym i średnim.

Dziennikarze prasy lokalnej nie poświęcili wiele uwagi przekształceniom w obrębie szkolnictwa zawodowego. W ciągu dwóch lat istnienia czasopisma na łamach „Wiadomości Mazurskich” pojawiło się 5 artykułów traktujących jedynie o wymaganiach rekrutacyjnych do tego typu szkół oraz poświęceniu im większej uwagi ze strony władz. Pierwszy z nich ukazał się w pierwszej dekadzie sierpnia 1945 r. Zamieszczano w nim informacje o uruchomieniu w Warszawie 4-letniego gimnazjum i 3-letniego liceum komunikacyjnego i zasadach rekrutowania do nich chłopców ${ }^{24}$.

Bezpośrednim nawiązaniem do kwestii tworzenia szkół zawodowych w regionie Warmii i Mazur była krótka publikacja dotycząca zapisów do Państwowego Liceum Komunikacyjnego w Olsztynie. Autor artykułu informował, że „zapisy przyjmuje Kancelaria Szkoły, [...] od godz. 9-tej do 12-tej. Do podania i życiorysu należy dołączyć: Świadectwo ukończenia Gimnazjum Ogólnokształcącego lub zawodowego, metrykę urodzenia. Dla kandydatów, którzy mają ukończonych 3 klas gimnazjum ogólnokształcącego lub zawodowego będzie uruchomiony kurs przygotowawczy. Do Gimnazjum Mechaniczno-Komunikacyjnego przyjmuje się kandydatów ze świadectwem ukończenia 6 oddziałów szkoły powszechnej. Przy przyjmowaniu kandydatów, pierwszeństwo mają dzieci pracowników kolejowych"25.

Mimo że w ciągu kolejnych dwóch lat na terenie Olsztyna uruchomiono następne szkoły zawodowe (Szkołę Handlową stopnia licealnego oraz Państwowe Żeńskie Gimnazjum Krawieckie), a cztery pozostawały w fazie organizacji (Państwowe Gimnazjum Mechaniczne w Ostródzie, Państwowe Gimnazjum Stolarskie w Reszlu, Zbiorcza Żeńska Szkoła Zawodowa w Olsztynie i Dokształcająca Szkoła Zawodowa w Olsztynie), tematyka ta nie została podjęta na łamach prasy olsztyńskiej.

Nieco więcej uwagi poświęcono szkolnictwu rolniczemu, gdyż w okresie niespełna dwóch lat ukazywania się „Wiadomości Mazurskich” szkolnictwu rolniczemu i jego organizacji w regionie poświęcono cztery publikacje. Pierwsza z nich

${ }^{23}$ Gwiazdka dzieci olsztyńskich, WM, 29 XII 1945, s. 2-3.

24 Z Życia Okręgu, WM, 9-10 VIII 1945, s. 2.

25 Tamże, WM, 18-19 IX 1945, s. 2. 
dotyczyła powołania Wydziału Oświaty Rolniczej przy Wojewódzkim Urzędzie Ziemskim. Informowano, że zadaniem tej instytucji jest organizacja i kontrola szkół rolniczych w regionie, a za realizację tych zadań na szczeblu powiatowym odpowiedzialne były jego organa terenowe, czyli Inspektoraty Oświaty Rolniczej przy Powiatowych Urzędach Ziemskich. „Zorganizowanych jest jedenaście inspektoratów, brak jeszcze sześciu. [...] Szkół jest nie dużo. Mamy ich na razie 12. Uczęszcza do nich przeszło 350 uczących się obojga płci"26.

Oceniano, że organizacja szkół rolniczych napawa optymizmem i rokuje nadzieje na przyszłość ze względu na aktywny w niej udział kadry pedagogicznej, która obok pracy dydaktycznej „prowadziła pionierską pracę w terenie”27. „Tworzący się zespól personelu nauczycielsko-instruktorskiego, który już rozpoczął i prowadzi prace w szkołach czynnych, w szkołach będących w organizacji i ogródkach szkolnych. Sami własnoręcznie czyszczą, reperują, doprowadzają budynki mieszkalne i gospodarcze do porządki oraz sieją, uprawiają ogródki warzywne..."28.

Uruchamianie szkół rolniczych w Okręgu Mazurskim stało się jednym z priorytetów edukacyjnych dotyczących szkolnictwa zawodowego - obok szkół o profilu przemysłowym i handlowym. Mimo że pod koniec 1946 r. w województwie olsztyńskim działało już 27 niższych szkół gminnych i powiatowych, zaś w kolejnym roku gminne szkoły rolnicze zostały przekształcone w szkoły przysposobienia rolniczego, a ich liczba wzrosła do 31 placówek z łączną liczbą 667 uczniów, ich problematyce nie poświęcono w prasie lokalnej większej uwagi.

Przebudowa ustroju szkolnego oraz zapotrzebowanie na kwalifikowanych pracowników w dużych gospodarstwach rolnych spowodowały zmiany w organizacji średniego szkolnictwa rolniczego. Szczególną uwagę zwrócono więc na rozwój dwóch typów szkół, jakimi były gimnazjum i liceum.

Pierwszymi szkołami średnimi o profilu rolniczym na terenie województwa olsztyńskiego były: Gimnazjum Gospodarstwa Wiejskiego w Szczytnie, Gimnazjum i Liceum Ogrodnicze w Olsztynie, Gimnazjum Gospodarstwa Wiejskiego w Giżycku, Liceum Rybackie w Giżycku, Gimnazjum i Liceum Gospodarstwa Wiejskiego w Olsztynie ${ }^{29}$, zaś pod koniec roku 1946 utworzono nowe szkoły stopnia gimnazjalnego i licealnego. Były to: Gimnazjum i Liceum Rolniczo-Hodowlane w Dobrocinie, Żeńskie Gimnazjum Gospodarstwa Wiejskiego w Morągu, Gimnazjum Rolnicze w Pasłęku ${ }^{30}$. Jednak w prasie lokalnej tej tematyce poświęcono jedynie trzy publikacje zamieszczone na łamach „Wiadomości Mazurskich”.

26 Oświata rolnicza w województwie Mazurskim, WM, 25 IV 1946, s. 3.

27 Tamże.

28 Tamże.

29 Sprawozdanie na sesję Wojewódzkiej Rady Narodowej z dn. 8 września 1947 r., APO, zespół: Prezydium Powiatowej Rady Narodowej i Urząd Powiatowy w Olsztynie, sygn. 451/92, za: A. S u chow ie cka, Edukacja zawodowa młodzieży na Warmii i Mazurach w latach 1945-1989, Olsztyn 2007, s. 38 [maszynopis rozprawy doktorskiej].

30 Rozwój oświaty rolniczej na Warmii i Mazurach, Ośrodek Badań Naukowych im. Wojciecha Kętrzyńskiego w Olsztynie, zespół: Zbiory Specjalne, sygn. R-158/IV/4, za: A. S u c h o w i e ck a, Edukacja zawodowa... 
Pierwsza z nich ukazała się w grudniu 1946 r. i dotyczyła pracy Gimnazjum Gospodarstwa Wiejskiego w Olsztynie. Pisano, że było to pierwsze gimnazjum wiejskie założone na Warmii i Mazurach, przygotowujące nauczycieli i instruktorów dla przyszłych szkół rolniczych oraz dla podniesienia poziomu wykształcenia fachowego gospodyń wiejskich ${ }^{31}$. Dobrze wykształcone kadry miały stać się podporą gospodarstw rolnych, stanowiących podstawę funkcjonowania województwa o ściśle rolniczym i hodowlanym charakterze. Pojawiły się także informacje o zapale do nauki młodzieży wiejskiej: „Uczniowie w 90\% pochodzą ze wsi, przeważnie z terenu naszego województwa. Młodzież garnie się z zapałem do nauki i uczy się świetnie"32.

Jak wynika z doniesień prasowych, trudności lokalowe będące konsekwencją dzielenia budynku gimnazjum z Liceum Ogrodniczym uniemożliwiały dalsze funkcjonowanie obydwu szkół. Stąd, z uwagi na wyjątkowość gimnazjum jako jedynej tego typu placówki w województwie, powinna ona „zasługiwać na większą troskliwość władz"33.

Z końcem grudnia 1946 r. w 32 gminnych szkołach rolniczych i 8 średnich kształciło się 400 uczniów i uczennic. W „Wiadomościach Mazurskich” pojawiła się publikacja wskazująca na bardzo ciężkie położenie materialne młodzieży uczęszczającej do średnich szkół rolniczych, rekrutującej się głownie spośród repatriantów i przesiedleńców z Polski centralnej. Autorzy artykułu apelują w nim o pomoc materialną, „która umożliwi kontynuowanie normalnej pracy w średnich szkołach rolniczych naszego województwa, które zapewnią chętnej i pilnej młodzieży chłopskiej należyte wyżywienie w okresie intensywnej pracy naukowej"34.

Nieco więcej uwagi poświęcono przygotowaniu zawodowemu kandydatów na fachowych rybaków z uwagi na funkcjonowanie gospodarstwa rybnego w Łuczanach. Pierwszą informacją, jaką zamieściły „Wiadomości Mazurskie” o rozpoczęciu kształcenia kadr rybackich, była notatka o przeprowadzeniu przeszkolenia rybackiego w liczbie 120 osób z Hufca Ligi Morskiej „pod kierunkiem ob. Dr Stolarzewicza, aby po przeszkoleniu udać się do Gdyni w celu kontynuowania nauki w Szkole Morskiej"35. W notatce znajdujemy też zapowiedź uruchomienia obok gimnazjum i średniej szkoły rolniczej, średniej szkoły rybackiej w Łuczanach.

W kolejnym roku ukazał się artykuł, w którym poinformowano o zadaniach, jakie miała realizować Państwowa Niższa Szkoła Rybacka w Łuczanach. Zasadność jej funkcjonowania argumentowano następująco:

[...] nie posiadamy odpowiedniej ilości fachowo wyszkolonego personelu rybackiego, rybaków, którzy by nie tylko mieli chwilowy dzisiejszy interes zarobkowy na celu, lecz patrzyli w przyszłość i pragnęli dla przyszłych pokoleń położyć podwaliny racjonalnego zagospodarowania jezior mazurskich, przyszłej podstawy jednej z najważniejszej gałęzi wyżywienia szerokich mas ludności. [...] Zadaniem

${ }^{31} \mathrm{Na}$ troskliwszą opiekę zasługuje Gimnazjum Gospodarstwa Wiejskiego w Olsztynie, WM, 1 VII 1946, s. 4.

32 Tamże.

33 Tamże.

34 Dopomóżmy młodzieży szkół rolniczych, WM, 31 XII 1946, s. 3.

35 Z życia Olsztyna, WM, 9 IX 1945, s. 3. 
Szkoły Rybackiej będzie położenie naukowych podstaw naukowych pod gospodarkę rybną, zbadanie naukowe ważniejszych jezior mazurskich [...] przygotowanie odpowiedniej ilości materiału zarybieniowego dla jezior mazurskich, aby nie tylko uczniowie szkoły, ale i inni rybacy mieli możność przekonania się naocznie o wzroście, o koniecznych warunkach życia dla pewnych gatunków ryb ucząc się praktycznie i teoretycznie przychodzić matce naturze z pomocą w rozmnażaniu rybostanu ${ }^{36}$.

Z informacji prasowych wynika, że szkoła ta cieszyła się wielkim uznaniem Mazurskiego Towarzystwa Rybackiego. Od początku swego istnienia „stało ono na stanowisku, iż lokalny interes rybactwa woj. olsztyńskiego wymagał powołania do życia przede wszystkim dobrze zorganizowanej państwowej niższej szkoły rybackiej dla kształcenia liniowego rybaka zawodowego, którego brak najbardziej daje się we znaki w ogóle, przede wszystkim zaś miejscowej gospodarce rybnej"37. Z uwagi na fakt, że obie strony wyrażały chęć nawiązania współpracy, wielkim zaskoczeniem dla przedstawicieli Towarzystwa okazał się fakt przekształcenia szkoły w Gimnazjum Rybackie „nie tylko bez porozumienia z zainteresowanymi w tej sprawie czynnikami rybackimi, lecz przeciwnie wbrew wyraźnej opinii tych czynników"38. W efekcie współpraca ze szkołą nie została nawiązana, co znalazło potwierdzenie w braku odpowiedzi na list członków Towarzystwa ze strony władz szkolnych. Artykuł zawierał też informacje o wystosowaniu w tej sprawie pisma do Ministerstwa Rolnictwa i Reform Rolnych, dotyczący rozpatrzenia omawianej sprawy.

Kwestia zapotrzebowania na kwalifikowane kadry znalazła odzwierciedlenie w publikacji pt. Musimy kształcić fachowców dla ruchu spółdzielczego. W artykule rozważano stworzenie odrębnego pionu edukacji na potrzeby przygotowania „fachowego pracowników spółdzielczych, gdyż [...] tylko niewielki procent pracowników spółdzielczych pracę swoją wykonuje prawidłowo"39. Cel taki miałyby realizować szkoły spółdzielcze. Celowość ich tworzenia autor artykułu uzasadnia „naprawieniem błędów przeszłości” i „osiągnięciem właściwej formy współżycia między ludźmi" ${ }^{40}$.

W ciągu dwóch lat wydawania "Wiadomości Mazurskich" na ich łamach pojawiły się 4 publikacje, których treść dotyczyła uruchomienia Uniwersytetu Ludowego w Rudziskach Pasymskich. Pisano, że z uwagi na potrzebę krzewienia oświaty wśród mas ludowych, głównym celem jego powstania była działalność repolonizacyjna wśród młodego pokolenia Mazurów, a także podtrzymywanie tradycji, zwyczajów i kultury rodzimej. Instytut Mazurski został założony 1 grudnia 1945 r. z inicjatywy Karola Małka i był jedną z dwóch placówek (obok Uniwersytetu Ludowego w Jurkowym Młynie) tego typu w regionie. Z informacji prasowych wynika, że „wykłady na Uniwersytecie prowadzili: ob. Sukiertowa-Biedrawina - Dzieje Mazur i Warmii, ob. Skurpski - Sztuka Mazurska, ob. Korolewicz-Wilamowski - Spółdzielczość, dr. Witkowski [w cytacie brakuje tytułu wykładu - A.K. i U.P.],

${ }^{36}$ Zagospodarowanie jezior mazurskich zadaniem Państwowej Szkoły Rybackiej w Łuczanach, WM, 25 IV 1946, s. 3.

${ }^{37}$ Niższa szkoła czy gimnazjum. Za niższą szkołą rybacką wypowiada się Mazurskie Towarzystwo Rybackie, WM, 18 II 1947, s. 3.

${ }^{38}$ Tamże.

${ }^{39}$ Musimy kształcić fachowców dla ruchu spółdzielczego, WM, 5 IV 1947, s. 3.

40 Tamże. 
ob. Leiding-Milecki, autor Słownika nazw na Mazurach i Warmii oraz dr. Szymański, autor dzieła Ratujmy Mazury Prus Wschodnich przed zagładą"41. O uruchomieniu Uniwersytetu informował także „Głos Ziemi”, w notatce znalazła się także zapowiedź zorganizowania drugiej tego typu placówki dla młodzieży warmińskiej - w Morągu ${ }^{42}$.

Doniesienia prasowe zawierają także oceny wartości tych placówek, na co wskazują sformułowania autorów artykułu, że Uniwersytet stał się „pożyteczną placówką oświatową i wychowawczą dla młodzieży autochtonicznej w wieku pozaszkolnym. [...] Zrywając pokost niemczyzny z młodych dusz daje ona Polsce nowe kadry ideowych obywateli, którzy naprawdę skutecznie będą mogli prowadzić szeroko zakrojoną akcję repolonizacyjną pośród swoich braci"43.

Uczestnicy kursów wywodzili się głównie ze środowisk rolniczych (70\%), w przeważającej liczbie były to dziewczęta. Jak relacjonują dziennikarze „Wiadomości Mazurskich", skład personalny uczestników drugiego kursu przedstawiał się następująco: „pod względem posiadanego wykształcenia słuchaczy M.U.L. można podzielić na dwie zasadnicze grupy: z wykształceniem szkoły powszechnej [...] i 4-6 klas gimnazjum niemieckiego. Oprócz tego jest jeden akademik i jedna maturzystka. Wiek waha się w granicach od 18 do 25 lat" 44 . Przedmiotami wykładanymi były: język polski, historia Polski, literatura polska, kultura ludowa, spółdzielczość, buchalteria i rachunkowość handlowa, rolnictwo, teatr ludowy i in.

Z rozmowy z Karolem Małkiem, dyrektorem Mazurskiego Uniwersytetu Ludowego w Pasymiu, zamieszczonej w grudniowym numerze „Wiadomości Mazurskich” wynika, że trudności materialne, z jakimi borykali się organizatorzy nie przyćmiły celów, jakimi było „wychowanie dobrego człowieka i obywatela oraz przebudzenie narodowe ludu mazurskiego poprzez kulturę ludową do narodowej"45.

Organizacją powojennej kultury i oświaty pozaszkolnej zajęło się także Towarzystwo Uniwersytetów Robotniczych (TUR). Powstała w 1923 r. socjalistyczna organizacja oświatowo-kulturalna zajmowała się samokształceniem, organizacją akcji odczytowych, działalnością wydawniczą, animowała ruch artystyczny wśród robotników. Organizowała także uniwersytety powszechne. W 1944 r. reaktywowało się z inicjatywy „lubelskiej” PPS, do 1948 r. liczyło 192 oddziałów wojewódzkich i powiatowych oraz ukierunkowało działalność na zintensyfikowanie form pracy z dorosłymi adekwatnie do realiów powojennej rzeczywistości.

Na łamach „Wiadomości Mazurskich” odnotowano także inicjatywy oświatowe TUR ${ }^{46}$ w regionie Warmii i Mazur. Poświęcono im w czasopiśmie 5 publikacji.

41 Pierwszy Uniwersytet Ludowy na Mazurach, WM, 21 XII 1945, s. 4.

42 Mazurski Uniwersytet Ludowy w Pasymiu, GZ, 25 XII 1945, nr 13, s. 3.

43 Serca budzące się z letargu. Zwiedzamy Uniwersytet Ludowy w Rudziskach pod Pasymiem, WM, 9 XI 1946, s. 3.

${ }_{44}$ Poprzez kulturę ludową do narodowej. Rozmowa z Karolem Małkiem, dyrektorem M.U.L., WM, 1 IX 1946, s. 3.

45 Tamże.

46 Organizacją powojennej kultury i oświaty pozaszkolnej zajęło się także Towarzystwo Uniwersytetów Robotniczych (TUR). Powstała w 1923 r. socjalistyczna organizacja oświatowo-kulturalna zajmowała się samokształceniem, organizacją akcji odczytowych, działalnością wydawniczą, animowała 
W listopadzie 1946 r. ukazał się artykuł zapowiadający uruchomienie w regionie pierwszego Uniwersytetu Powszechnego w Olsztynie. Jak wynika z doniesień prasowych, „słuchaczami mogą być wszyscy, którzy ukończyli 18 lat i mogą wykazać się świadectwami, względnie sprawdzonymi wiadomościami z zakresu siedmiu klas szkoły powszechnej. [...] Nauka jest bezpłatna i odbywa się w godzinach popołudniowych (3 godz. dziennie). Kurs Uniwersytetu powszechnego przewidziany jest na lat $2 " 47$. W ramach potwierdzenia nabytych kwalifikacji uniwersytet wydawał świadectwa honorowane przez Ministerstwo Oświaty. Na pierwszy kurs zgłosiło się 100 kandydatów w wieku od 24 do 28 lat.

W kolejnej publikacji z 23 listopada jej autorzy informowali o ukonstytuowaniu się 28 sierpnia Zarządu Wojewódzkiego TUR, jego składzie osobowym oraz planach w zakresie realizacji najważniejszych zadań dotyczących budowy Domu Kultury i organizacji uruchomionego Uniwersytetu Powszechnego. Obok zamieszczenia ponownych informacji o zasadach rekrutacji kandydatów i programie nauki w kolejnych dwóch latach działalności autorzy zwrócili uwagę na entuzjazm młodzieży robotniczej z województwa olsztyńskiego w związku ze stworzeniem możliwości kontynuowania nauki i uzyskiwania kwalifikacji zawodowych w różnych dziedzinach gospodarki. Pisano:

W ten sposób przygotowuje się w Polsce ludzi, którzy mogą być nie tylko świadomymi pionierami, ale i fachowymi pracownikami w spółdzielczości, administracji państw. i samorządowej oraz kierownikami placówek oświatowych ${ }^{48}$.

Bezpośrednią realizacją zadań oświatowo-kulturalnych zajęły się koła powiatowe, których „szlachetna rywalizacja [...] przyniesie pożytek i zadowolenie nie tylko TUR-owcom, ale i szerokim masom społeczeństwa"49.

Trzecia publikacja pt. Dom Kultury stanie się ośrodkiem życia kulturalnego ${ }^{50}$, obok ogólnych informacji o potrzebie organizacji Uniwersytetu Powszechnego, została w dużej mierze poświęcona kwestii budowy domu kultury w Olsztynie. Znajdujemy w niej wyszczególnienie poniesionych kosztów i subwencji przyznanych na jego tworzenie ze strony lokalnych władz administracyjnych i oświatowych.

Krótką notatkę prasową poświęcono także organizowaniu przez TUR Uniwersytetu Niedzielnego, przeznaczonego „dla ludzi pracy, którzy chcą się kształcić, by móc brać aktywny udział w życiu państwa"51.

Już w 1926 r. z TUR wyłoniła się odrębna socjalistyczna organizacja młodzieżowa (OM TUR), ukierunkowana na działalność kulturalną i sportową dla młodzieży wywodzącej się ze środowiska robotniczego. Jak wynika z wywiadu

ruch artystyczny wśród robotników, organizowała także uniwersytety powszechne. W 1944 r. reaktywowało się z inicjatywy „lubelskiej” PPS i do 1948 r. liczyło 192 oddziałów wojewódzkich i powiatowych oraz ukierunkowało działalność na zintensyfikowanie form pracy z dorosłymi adekwatnie do realiów powojennej rzeczywistości.

${ }^{47}$ Uniwersytet Powszechny TUR powstaje w Olsztynie, WM, 9 XI 1946, s. 3.

48 TUR szerzy oświatę i kulturę na Warmii i Mazurach, WM, 23 XI 1946, s. 4.

49 Tamże.

${ }^{50}$ Dom Kultury stanie się ośrodkiem życia kulturalnego, WM, 31 XII 1946, s. 3.

51 Uniwersytet Niedzielny TUR nowym ośrodkiem kształcenia w Olsztynie, WM, 16 II 1947, s. 5. 
przeprowadzonego z sekretarzem Komitetu Wojewódzkiego OM TUR, Jerzym Eljasiewiczem, zamieszczonym na łamach „Wiadomości Mazurskich” w lutym 1946 r., praca oświatowo-kulturalna koncentrowała się wokół organizowania odczytów w obrębie kół prelegentów oraz działalności sekcji: sportowej, dyskusyjnej, imprezowej i innych, w zależności od zainteresowań młodzieży ${ }^{52}$.

Dopełnieniem organizacji oświaty pozaszkolnej w Olsztyńskiem były: działalność spółdzielni księgarskich i wydawniczych, organizacja kół prelegentów, akcje upowszechniania bibliotek i księgarni. Informacje na ten temat zamieszczono trzykrotnie na łamach „Wiadomości Mazurskich”.

W początkowym okresie organizacji oświaty w regionie szkoły powstawały w najbardziej nieoczekiwanych miejscach, „słowem rosły szkoły... rosły dziko od przypadku do przypadku"53. Stan taki utrzymywał się do września 1946 r., do momentu utworzenia Kuratorium Okręgu Szkolnego, które przejęło 72 „dzikie” szkoły i 117 nieopłacanych nauczycieli54.

Stopniowe zwiększanie się liczby nauczycieli powodowało objęcie nauczaniem coraz większej liczby dzieci i młodzieży. Dynamikę zmian zachodzących w organizacji szkolnictwa na poszczególnych szczeblach edukacji przedstawiono szczegółowo w publikacji z 24 listopada 1946 r. zatytułowanej Roczny dorobek nauczycielstwa na odzyskanej ziemi warmińsko-mazurskiej. Autorzy dokonali w niej prezentacji danych liczbowych obrazujących dorobek oświatowy w regionie. Jak wynika z doniesień prasowych, w październiku 1946 r. na terenie Okręgu Mazurskiego czynnych było 635 szkół powszechnych z ponad 1500 nauczycielami, sprawującymi opiekę nad 54500 dzieci objętych obowiązkiem szkolnym ${ }^{55}$.

Repolonizacja miejscowej ludności stanowiła po wojnie jeden z głównych celów oświatowych. Poprawa znajomości języka polskiego traktowana była jako sposób podniesienia wykształcenia, ale też jako „instrument przyspieszania procesu integracji i wiązania ludności rodzimej z polskością" ${ }^{6}$. Dlatego uczęszczanie do szkól powszechnych ponad 10 tysięcy polskiej ludności autochtonicznej, będące m.in. efektem przeprowadzonej akcji weryfikacyjnej, stanowiło - zdaniem dziennikarzy - „ogromny czynnik postępu”.

Jak wynika $z$ informacji zamieszczonych w wymienionej publikacji, ogółem czynnych było 15 szkól średnich ogólnokształcących z 2374 uczniami i 111 nauczycielami, przy jednoczesnym braku 62 nauczycieli57. Stan liczbowy szkól zawodowych również wskazywał na ich powolny rozwój. Funkcjonowały trzy szkoły przemysłowe, dwie handlowe i spółdzielcze, jedna dokształcająca zawodowa oraz kilka liceów pedagogicznych, kształcących 611 nauczycieli. Po raz pierwszy zwrócono uwagę na rozwój przedszkoli, w których pod koniec października 1946 r. pracowało 245 wychowawczyń opiekujących się 7 tys. dzieci58 ${ }^{5}$.

\footnotetext{
52 Organizacja młodzieżowa TUR, WM, 17 II 1946, s. 4.

53 Roczny dorobek..., s. 3.

54 Tamże.

55 Tamże.

56 U Pulińs k a, Doskonalenie zawodowe..., s. 23.

57 Roczny dorobek...

58 Tamże.
} 
W artykule zamieszczono informacje dotyczące dorobku kuratorium w ramach organizacji oświaty i kultury dorosłych. Wynika z nich, że „na 92 kursach repolonizacyjnych o 106 klasach uczęszczało 2747 autochtonów, w tym 2130 kobiet, przy czym nauka trwała 15527 godzin, pracowało zaś 112 nauczycieli. [...] Na kursach dokształcających w zakresie szkoły powszechnej uczęszczało 1739 uczniów. [...] W dwóch szkołach powszechnych dla dorosłych o 5 klasach uczęszczało 118 uczniów, zaś [...] w 31 klasach gimnazjum dla dorosłych pobierało naukę 368 mężczyzn i 292 kobiety"59.

Tekst zamyka informacja o działalności dwóch uniwersytetów ludowych, realizujących zajęcia dla 26 mężczyzn i 61 kobiet, pracy kół prelegentów oraz prowadzeniu zajęć świetlicowych dla 2672 uczestników.

Z uwagi na wielkie zapotrzebowanie na absolwentów uczelni wyższych, ważnym wydarzeniem stało się otwarcie pierwszej w regionie szkoły wyższej - Akademii Administracyjnej dla Ziem Odzyskanych. Pierwsze informacje prasowe na ten temat pojawiły się w sierpniu 1945 r. na łamach „Wiadomości Mazurskich” i „Głosu Ziemi”. Informowano o powołaniu Oddziału Olsztyńskiego Akademii Administracji Publicznej oraz składzie Komitetu Organizacyjnego Akademii. Jak wynika z doniesień prasowych, stanowili go: pełnomocnik rządu R.P. płk Prawin, wicewojewoda Burski, prof. dr Hilarowicz i inni ${ }^{60}$. Podkreślano znaczenie utworzenia uczelni wyższej na terenie Ziem Odzyskanych dla szybszego rozwoju regionu ponownie przywróconego w granice Rzeczypospolitej Polskiej i kształcenia kadr dla administracji kraju.

Z kolejnych publikacji wynika, że rektorem uczelni został prof. dr T. Hilarowicz, jednocześnie rektor Akademii Administracyjnej w Łodzi, zaś wśród wykładowców znaleźli się m.in. prof. Sukiertowa-Biedrawina, była kustosz Muzeum Mazurskiego w Działdowie, prof. Mokulski i in. Na pierwszy kurs zapisało się 100 kandydatów $^{61}$. Studenci przystąpili do utworzenia Koła Samopomocy, zajmującego się przede wszystkim przygotowaniem skryptów do nauki ${ }^{62}$

Z uwagi na trudności lokalowe, wykłady odbywały się w sali konferencyjnej Urzędu Pełnomocnika Rządu, której rozmiary nie pozwalały jednak na stworzenie dogodnych warunków nauki: „Wielu słuchaczy stoi na wykładach, co uniemożliwia robienie notatek, które stanowią przecież podstawę nauki”63.

Z biegiem czasu informowano czytelników o planowanych zmianach w organizacji uczelni. Z powodu braku profesorów, którzy mieliby na stałe przebywać w Olsztynie oraz niesprostania wymogom formalnym, stawianym uczelniom o prawach akademickich, podjęto decyzję o przekształceniu Akademii w Wyższą Szkołę Prawa i Administracji. Zgodnie z decyzją Ministerstwa Oświaty, „uprawnienia oczywiście będą mniejsze, bo absolwenci Wyższej Szkoły Prawa i Administracji w Olsztynie nie będą mogli ubiegać się o doktora czy magistra. Nie ma to

59 Tamże.

60 Zob. Okręg Mazurski zyskuje wyższą uczelnię, WM, 16-18 VIII 1945; zob. także: Wiadomości z Olsztyna, GZ, sierpień 1945, s. 3.

61 Akademia Administracyjna - pierwsza wyższa uczelnia w Olsztynie, WM, 18 XII 1945, s. 3.

62 Z Akademii Administracyjnej w Olsztynie, GZ, 18 XI 1945, nr 19, s. 4.

63 Tamże. 
jednak większego praktycznego znaczenia, bo można będzie wszystkie te tytuły uzyskać na każdym Uniwersytecie"64.

Uruchomienie Wyższej Szkoły Prawno-Ekonomicznej65 stało się ważnym osiągnięciem naukowo-kulturalnym Olsztyna. Pomimo trudności lokalowych i kadrowych było przykładem sprawnej organizacji, wynikającej z dobrej woli i nastawienia jej twórców oraz pracującej kadry naukowo-dydaktycznej. Już po półrocznym okresie działalności rozszerzył się program studiów prawno-ekonomicznych. W jednym z artykułów informujących o dorobku uczelni, zamieszczonym na łamach „Wiadomości Mazurskich” w kwietniu 1946 r. zaprezentowano szeroki wachlarz wykładanych przedmiotów, zaś wśród wykładowców pojawiły się takie nazwiska, jak: E. Sukiertowa-Biedrawina (historia Warmii i Mazur oraz lokalnego ruchu narodowego), prof. dr T. Hilarowicz (ogólna teoria prawa i konwersatorium, nauka administracji i ogólna teoria prawa administracyjnego, prawo kościelne, postępowanie administracyjne oraz wstęp do nauki prawa rzymskiego i wstęp do historii prawa na Zachodzie Europy), ob. J. Sekita, prezes Sądu Okręgowego w Olsztynie (ogólna teoria prawa), mgr J. Trzopek, b. wiceprezydent Olsztyna (historia ustroju państw na zachodzie Europy, postępowanie administracyjne z ćwiczeniami), sędzia Sądu Okręgowego A. Wojskiewicz (dawne prawo sądowe polskie, historia i instytucje prawa rzymskiego), mgr A. Feliksiewicz (teoria prawa administracyjnego i konwersatorium z teorii prawa), ob. F. Moczulski (stosunki gospodarcze Związku Radzieckiego na tle historii lat ostatnich) i inni66. W artykule pisano:

Tygodniowo słuchacze mają 19 godzin wykładów. Wykłady odbywają się od godz. 16 do 20, aby umożliwić pracującym uczęszczanie na wykłady. Do uczelni zapisanych jest 1897 słuchaczów i słuchaczek, wśród nich wielu z maturami licealnymi. Prawie wszyscy są pracownikami administracji publicznej (urzędu wojewódzkiego, zarządu miejskiego, dyrekcji kolejowej, izby skarbowej, urzędu ziemskiego, itd. $)^{67}$.

W niedalekiej przyszłości wykłady z zakresu historii ziem odzyskanych i historii ustroju Polski rozpocząć miał także prof. dr S. Zajączkowski, były prorektor uniwersytetu w Wilnie ${ }^{68}$. Jak podkreśla autor artykułu, biorąc pod uwagę program studiów, uwzględniono w nim zarówno wiedzę specjalistyczną, jak i regionalny charakter treści.

We wrześniu 1946 r. ukazała się informacja prasowa o wizycie delegacji Wyższej Szkoły Prawno-Ekonomicznej u ministra Czesława Wycecha w sprawie

64 Młodzież akademicka na start, WM, 1 II 1946, s. 3.

65 Według S. Achremczyka, Akademia Administracyjna przekształcona została w Wyższą Szkołę Prawno-Ekonomiczną, a ta z kolei w filię Wydziału Prawno-Ekonomicznego Uniwersytetu Mikołaja Kopernika pod nazwą Studium Prawno-Administracyjne. W artykułach prasowych autorzy stosują pełną dowolność w nazewnictwie placówki, używając także nazwy Wyższa Szkoła Prawa i Administracji, co nie jest zgodne z faktycznym nazewnictwem. Por. Olsztyn 1353-2003, red. S. Achremczyk, W. Ogrodziński, Olsztyn 2003, s. 446.

66 T. Hila rowicz, Poważne osiągnięcie naukowo-kulturalne. Półroczny dorobek pierwszej wyższej uczelni w Olsztynie, WM, 26 IV 1946, s. 3.

67 Tamże.

68 Tamże. 
utworzenia w Olsztynie Wydziału Prawno-Ekonomicznego Uniwersytetu Toruńskiego (Studium Prawno-Ekonomiczne), co stało się faktem kilka miesięcy później. Istotnym wydarzeniem medialnym stało się przydzielenie lokalu na Studium w gmachu starego Ratusza. Informacje dotyczące remontu budynku oraz powołania Komitetu Organizacyjnego pod przewodnictwem wojewody dr Z. Robla ukazały się w „Wiadomościach Mazurskich” w marcu 1947 r. Wskazywano na „wielką ofiarność studentów i studentek uczelni, której przedstawiciele w komitecie zadeklarowali na odbudowę sumę 100000 zł"69. Jako główne źródło finansowania „środki pieniężne mają być zebrane w drodze zbiórki powszechnej. W tym celu komitet odwoła się do ofiarności społeczeństwa z wiarą, że ogół ludności województwa, a zwłaszcza m. Olsztyna, nie odmówi mu swego poparcia"70. Kwestia stałej lokalizacji Studium okazała się o tyle istotna, o ile „w łonie Związku Nauczycielstwa Polskiego powstała myśl rozszerzenia studium o wydziały humanistyczne i matematyczno-przyrodnicze"71.

W roku akademickim 1946/1947 studium liczyło już 420 słuchaczy, a w kolejnym roku ich liczba sięgała 800 osób. Jednak pomimo znacznego liczebnego wzrostu studiujących, Ministerstwo Oświaty zdecydowało o likwidacji szkoły w połowie 1948 r. Ostatecznie, żywot Studium zakończył się wiosną 1950 r. $^{72}$

Jak wynika z przedstawionego omówienia, problematyka szkolnictwa i oświaty nie była tematem pierwszoplanowym na łamach prasy olsztyńskiej w latach 1945-1947. Nie oznacza to jednak, że badacz dziejów edukacji na Warmii i Mazurach nie odnajdzie tam interesujących informacji.

\footnotetext{
69 Stary Ratusz będzie odbudowany dla Studium Prawno-Administracyjnego, WM, 30 III 1947, s. 5.

70 Tamże.

71 Rozbudowa uczelni olsztyńskiej zależy od pomocy społeczeństwa, WM, 9 II 1947, s. 3.

72 Olsztyn 1353-2003...
} 